\title{
A távmunka széleskörü elterjedésének lehetséges hatása a magyarországi vándormozgalmi mintázatokra ${ }^{1}$
}

\section{The possible future effects of widespread home office on the Hungarian internal migration patterns}

\section{LENNERT JÓZSEF}

\begin{abstract}
LENNERT József: tudományos munkatárs, Közgazdaság- és Regionális Tudományi Kutatóközpont, Regionális Kutatások Intézete; 6000 Kecskemét, Rákóczi út 3., lennert.jozsef@krtk.mta.hu; https://orcid.org/0000-0002-2653-3791
\end{abstract}

KULCSSZAVAK: távmunka; belső vándormozgalom; jóléti migráció; budapesti agglomeráció

József LENNERT: research fellow, Centre for Economic and Regional Studies, Institute for Regional Studies; Rákóczi út 3., H-6000 Kecskemét, Hungary; lennert.jozsef@krtk.mta.hu; https://orcid.org/ 0000-0002-2653-3791

KEYWORDS: home office; internal migration; amenity migration; Budapest Metropolitan Area

A COVID-19 pandémia lehetséges közép- és hosszútávú társadalmi-gazdasági hatásairól szóló diskurzusokban rendszeresen felmerül, hogy a most életbe léptetett válságmegoldások megnyithatják az utat az érintett technológiák és gyakorlatok széleskörü elterjedéséhez. Ezek egyikeként a távmunkát szokták kiemelni (index.hu 2020a). E munkaszervezési gyakorlat mainál tágabb körű (globális és hazai) alkalmazásának elmaradása elsősorban nem a technikai akadályoknak, hanem az érintett cégek és intézmények tartózkodásának köszönhető. Ezen változtathat a koronavírus okozta válsághelyzet a home office bevezetésével olyan szervezetek esetében is, ahol ez eddig nem volt része a munkahelyi kultúrának. A német munkaügyi és szociális minisztérium közelmúltban nyilvánosságra hozott javaslata (index.hu 2020b), miszerint törvényben rögzítenék a munkavállalók otthoni munkavégzéshez való jogát (azokban a munkakörökben, ahol ez lehetséges), szintén arra enged következtetni, hogy a fertőzésveszély elmúlta után is számolhatunk a magasabb arányú távmunkavégzés fennmaradásával.

A távmunka szélesebb körü elterjedésének pozitív hatásai és árnyoldalai egyaránt lehetnek - egyik legnagyobb lehetséges kockázatának a munka és magánélet közötti határ további elmosódását tartják (bbc.com 2020), amire a már idézett német javaslattervezet is kitér. Jelen gyorselemzésemben a távmunka széleskörű elterjedésének társadalmi-gazdasági következményei közül arra keresem a választ, hogy ez milyen hatást gyakorolhat a magyarországi belső vándormozgalom jövőbeli mintázatára. 
E gyorselemzés hátterét a magyarországi természetes népmozgalmi és belső vándormozgalmi folyamatok területi modellezését és 2051-ig történő előrejelzését megvalósító kutatás adja, amiből a Területi Statisztika 2019. évi 5. számában jelent meg összegző tanulmány (Lennert 2019). E kutatásban számos lehetséges forgatókönyv mentén vizsgáltam meg hazánk demográfiai jövőképét. $\mathrm{E}$ forgatókönyvek közül az atipikus foglalkoztatási formák és az autonóm közlekedés jövőbeli fokozott térnyerésével számoló szcenáriók relevanciája az elmúlt hónapokban megnövekedett, gyorselemzésemben ezek legfontosabb eredményeit mutatnám be.

A KSH adatfelvétele alapján 2018 első negyedévében mintegy 144000 fö (az alkalmazottak 3,7\%-a) dolgozott távmunkában, illetve home office-ban (KSH 2020). Ezzel szemben az Európai Unióban átlagosan 5\% az ilyen módon foglalkoztatottak aránya (2017), de egyes országokban (Hollandia, Finnország) akár a népesség 10\%-át is meghaladhatja (Európai Bizottság 2018). Ez önmagában mutatja, hogy hazánkban is van tér az atipikus foglalkoztatási formák szélesebb körű elterjedése előtt.

A lakóhely és munkahely földrajzi kapcsolatának átalakulása, a napi ingázási kényszer csökkenése a rugalmasabb lakóhelyválasztást is lehetővé teszi. Nyugat-Európában és az angolszász országokban a migrációs áramlatok egy jelentős része a jóléti migrációként ('amenity migration') írható le (Abrams et al. 2012), amelynek során a lakóhelyváltók életminőségük javítása érdekében a vonzó természeti adottságokkal rendelkező (jellemzően vidéki) településeket részesítik előnyben (Moss 2006), függetlenül attól, hogy az adott település nagyvárosi ingázóöv részét képezi-e (ebben élesen elkülönülve a nagyvárosi ingázóövekre korlátozódó szuburbanizációtól). E folyamat (aminek kiemelt résztvevői a nyugdíjas korosztály, illetve a távmunkában dolgozók) a fejlett világban egyes nagyvárosi központoktól távol eső, ám vonzó természeti környezetű vidéki térségek megújulásához vezetett (ám térben igen szelektíven). Hazánkban a jóléti migrációnak még csak a csíráit láthatjuk, de az atipikus foglalkoztatási formák elterjedésével nagyobb jelentőséget kaphat.

A távmunka jelenleginél általánosabbá válásával számoló szcenárió futtatása esetén 2051-ig mintegy 160000 fö választott eltérő járást lakóhelyéül a korábbi trendek folytatódását feltételező alapforgatókönyvhöz képest. A változtatás hatása térben meglehetősen korlátozottan jelentkezett (1. ábra).

A vándorlási egyenleg legjelentősebb romlása a budapesti agglomeráció belső gyürüjébe tartozó járásokban jelentkezett. Ezt viszont nem kell feltétlenül negatív társadalmi folyamatként értelmezni: az utóbbi évtizedekben a Budapestet körülvevő járásokra az intenzív szuburbanizáció komoly környezeti, infrastrukturális és gazdasági többletterhelést rótt. A 2010-es évek trendjeit felhasználó forgatókönyvben ez a folyamat töretlen maradt - ezzel szemben a távmunka jelenleginél általánosabbá válásával számoló szcenárióban jósolt számottevően csökkenő vándorlási többlet fellélegzést hozhat a már most is jelentős népességet koncentráló belső gyűrünek. 
1. ábra: Belső vándorlási egyenleg a 2011-2051-es időszakra: az atipikus foglalkoztatási formák előtérbe kerülésével számoló forgatókönyv okozta eltérés az alapforgatókönyvhöz képest The forecasted internal migration balance for 2011-2051: differences between the 'atipical employment' and base scenarios

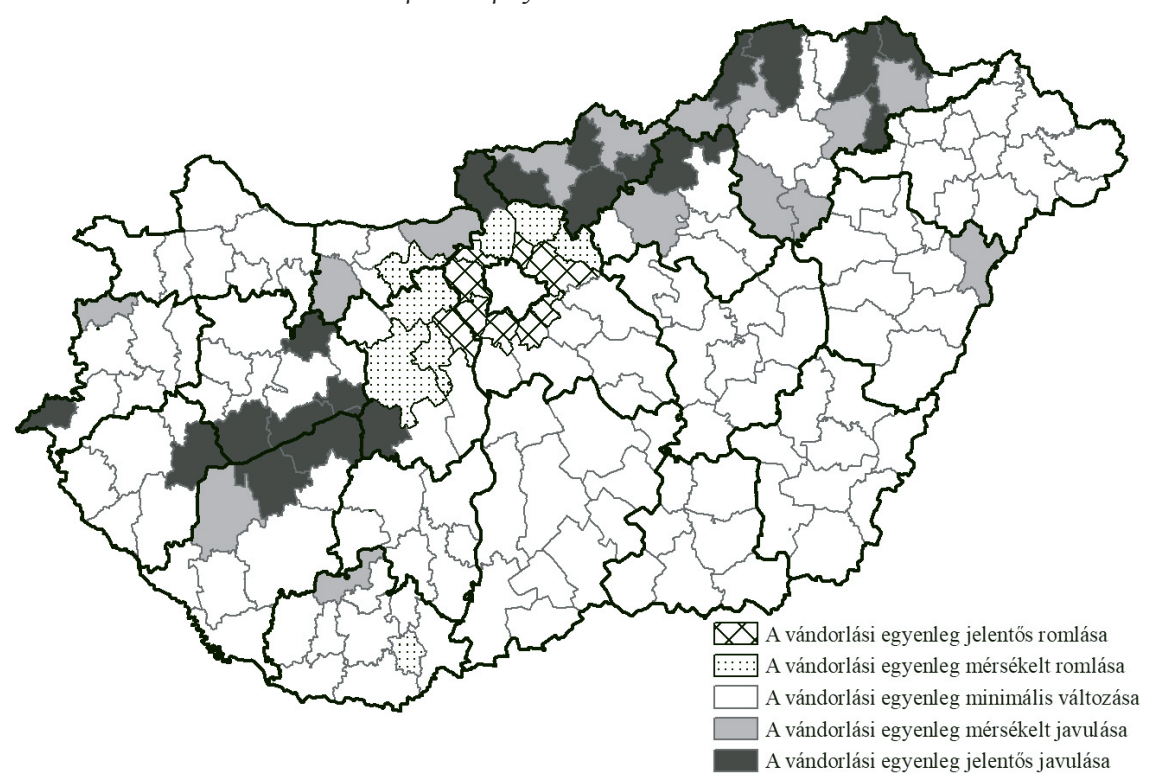

Forrás: saját modellszámítás, a KSH, a Teir (NAV), az UNdata, az Eurostat, az Európai Környezetvédelmi Ügynökség, a GoogleMaps és a Cordex klímaadatbázis adatainak felhasználásával

A fơvárosi agglomeráció külső gyűrűjében a vándorlási egyenleg már kisebb mértékben romlik az alapforgatókönyvhöz képest, míg az agglomeráció mai peremén található Szobi, Rétsági és Pásztói járások esetében már jelentős többletvándorlást okozna a távmunka széleskörü elterjedésével számoló forgatókönyv. Ezekből a járásokból a fóvárosba irányuló napi ingázás lehetséges ugyan, de rendkívül nehézkes (a népesség számottevő része már nem is közvetlenül a fővárosba, hanem az agglomeráció alközpontjaiba, például Vácra ingázik). Viszont kellemes természeti környezetük, valamint olcsóbb ingatlanáraik miatt vonzók lehetnek azok számára, akik kötődnek a fővárosi munkaerőpiachoz, de rugalmas/ atipikus foglakozási formájuknak köszönhetően már nem napi rendszerességgel kell ingázniuk. Ezen térség iránt megnövekedett érdeklődésnek a kezdeti jelei már ma is láthatók, például a Börzsöny előterében található települések esetében. Összességében tehát elmondható, hogy az atipikus foglalkoztatási formák széleskörű elterjedésével számoló forgatókönyv a fővárosi agglomeráció további szétterülését jelzi előre, annak minden társadalmi és környezeti előnyével és hátrányával együtt.

Az atipikus foglalkoztatási formák széleskörű elterjedésével számoló forgatókönyv a vándorlási egyenleg jelentős javulásával számol továbbá a Balaton térségében is. A part menti üdülőtelepüléseken túlmutató élénkülés már a rendszerváltás 
után megindult: a Káli-medence például igen hamar a jóléti migráció célterületévé vált (Fejős, Szijártó 2002). Ez a tendencia kiterjedhet és felerősödhet a jövőben. A vándorlási többlet egy része vélhetően (és remélhetőleg) nem támaszt új lakhatási igényt: a nyaralók és üdülők tulajdonosai (távmunkában dolgozva) az év mind nagyobb részében tudják lakhatásra használni második otthonukat, akár állandó otttartózkodásra is berendezkedve. Ennek következtében a települések szezonális és állandó lakossága közötti különbség csökkenése várható.

Az éghajlatváltozás hatásainak fokozottabb jelentkezésével vonzó természeti környezetük mellett kedvezőbb klimatikus viszonyaik miatt várhatóan a hegy- és dombvidéki területek iránt is megnövekszik az érdeklődés, és a távmunka szélesebb körű elterjedése többek számára teremtene lehetőséget ennek kihasználására. Egyes dunántúli célterületek (Őrség, Kőszeg, Bakony) mellett a modellfuttatás az Északi-középhegységben jelzett előre számottevő többletvándorlást. Ennek jelentkezése várhatóan térben igen differenciált lesz: meglévő társadalmi adottságaiktól függően várhatóan egymás mellett léteznek majd továbbra is az elnéptelenedéssel sújtott, a szegregálódó és a jóléti migráció célterületévé váló települések.

Figyelemre méltó továbbá, hogy az atipikus foglalkoztatási formák széleskörủ elterjedésével számoló forgatókönyv futtatása nem okozott jelentős elmozdulást az alapforgatókönyvhöz képest sem a nagyvárosi központokban - amelyek továbbra is vonzók maradtak elsősorban a fiatalabb korosztályok számára -, sem a vidéki térségek jó részében (például az alföldi járások többsége), ahol ugyan a távmunka elterjedése csökkentette valamelyest a vándorlási veszteséget, ám továbbra is fokozatos elnéptelenedéssel kénytelenek szembenézni.

\section{Jegyzetek}

1 Kézirat lezárva: 2020. 04. 27. A szöveg korábbi változata műhelytanulmányként megjelent a Regionális Kutatások Intézetének weboldalán: http://www.rkk.hu/hu/covid-19-kutatasok/ gyorselemzesek.html

\section{Köszönetnyilvánítás}

A Magyarország XXI. századi társadalmi-gazdasági térfolyamatainak komplex modellezési lehetőségei PD 128372 számú projekt a Nemzeti Kutatási Fejlesztési és Innovációs Alapból biztosított támogatással, a PD_18 pályázati program finanszírozásában valósult meg.

Jelen tanulmány egyes eredményei a Környezeti és Energiahatékonysági Operatív Program (KEHOP) által támogatott, a KEHOP-1.1.0-15-2016-00007 pályázati azonosítószámú, a „NATéR továbbfejlesztése" elnevezésű projekt keretében megvalósult kutatáshoz kapcsolódnak. 


\section{Irodalom}

Abrams, J. B., Gosnell, H., Gill, N. J., Klepeis, P. J. (2012): Re-creating the Rural, Reconstructing Nature: An International Literature Review of the Environmental Implications of Amenity Migration. Conservation and Society, 3., 270-284. https://doi.org/10.4103/0972-4923.101837

Európai Bizottság (2018): Working from home in the EU. https://ec.europa.eu/eurostat/web/productseurostat-news/-/DDN-20180620-1 (Letöltve: 2020. április 8.)

Fejős, Z., Szijártó, Zs. (2002): Egy tér alakváltozásai: esettanulmányok a Káli-medencéról. Néprajzi Múzeum, Budapest (Tabula könyvek 4.)

KSH (2020): Távmunka és „home office”. KSH, Budapest http://www.ksh.hu/docs/hun/xftp/idoszaki/ munkerohelyz/tavmunka/index.html (Letöltve: 2020. április 8.)

Lennert J. (2019): A magyar vidék demográfiai jövőképe 2051-ig, különös tekintettel a klímaváltozás szerepére a belső vándormozgalom alakításában. Területi Statisztika, 5., 498-525. https:// doi.org/10.15196/TS590503

Moss, L. A. G. (eds.) (2006): The amenity migrants: Seeking and sustaining mountains and their cultures. CAB International, Cambridge https://doi.org/10.1079/9780851990842.0000

\section{Internetes források}

https://www.bbc.com/worklife/article/20200309-coronavirus-covid-19-advice-chinas-workat-home-experiment (Letöltve: 2020. április 27.)

https://index.hu/velemeny/2020/04/06/milyen_lesz_a_vilag_a_virus_utan/ (Letöltve: 2020. április 8.) https://index.hu/gazdasag/2020/04/26/nemetorszagban_a_jarvany_utan_is_munkavallaloi_jog_lenne_a_home_office/ (Letöltve: 2020. április 27.) 